\title{
Intervention in the Effort of Decreasing Anemia Incidence to Students of SMA N 4 Cikupa Kabupaten Tangerang
}

\author{
Yohanes Firmansyah ${ }^{1}$, Gabriella Hafidha Badruddin ${ }^{1}$, Lidya Christiani ${ }^{1}$, Ernawati Su${ }^{2}$ \\ 1. Faculty of Medicine, Tarumanagara University, Jakarta, Indonesia \\ 2. Public Health and Family Medicine, Faculty of Medicine, Tarumanagara University, \\ Jakarta, Indonesia \\ *corresponding author, e-mail: yohanesfirmansyah28@gmail.com
}

Received: 05/06/2020; published: 30/03/2021

\begin{abstract}
Background: A survey conducted by the World Health Organization (WHO) in the span of time between 1993 and 2005 found that 1.62 billion people in the world had anemia, or around $24.8 \%$ of the world's population, with $30.2 \%$ (468 million) reproductive aged women. The research is a descriptive study as a means to perform early detection of anemia in adolescent girls with interventions in the form of counseling, improve adolescent knowledge, and improve adolescent attitudes and behavior at High School or Sekolah Menengah Atas Negeri (SMA N) 4 Cikupa. Method: This research is a descriptive quantitative analytic study where the sample was selected by simple random sampling. The population in this study were students of 4 Cikupa, Tangerang Regency of SMA N 4, Cikupa, Tangerang Regency. Results: The results of the study were $(97.72 \%)$ respondents had increased their knowledge after counseling and $(72.72 \%)$ respondents had improved their behavior and attitudes toward anemia. Participants (25\%) were diagnosed with anemia and $(75 \%)$ did not have anemia. Conclusion: improved knowledge is an important factor in reducing the prevalence of anemia in adolescent girls.
\end{abstract}

Keywords: anemia; adolescent girls; health promotion

Copyright $\odot 2013$ Universitas Ahmad Dahlan. All rights reserved.

\section{Introduction}

Anemia is a condition where the blood has low concentration of hemoglobin which results in unmet physiological needs. Anemia has become a public health problem and also affects people's income, welfare, social and economy. Anemia is prevalent and occurs in various countries, both developed and developing countries [1-3]. Solving anemia cases cannot only be done on one side. Anemia is multifactorial, including physiological factors such as pregnancy, nutritional problems such as iron and vitamin deficiency, health problems such as bleeding, chronic infections and chronic diseases [4] and physiological needs such as age, sex, occupation, place of residence, certain medical conditions, pregnancy and lifestyle of the individual $[5,6]$.

The survey data of World Health Organization (WHO) showed that the prevalence of anemia in Southeast Asia is $14.9 \%$. There were three affected groups of population with the highest number of anemia i.e. $41.8 \%$ pregnant women, $30.2 \%$ reproductive-aged women, and $12.7 \%$ reproductive-aged men [5]. According to the Ministry of Health of the Republic of Indonesia or Kementerian Kesehatan Republik Indonesia (Kemenkes RI), the prevalence of anemia in young girls was $37.1 \%$ in 2013 and has increased to $48.9 \%$ in 2018 [7,8]. The high prevalence of anemia among women of reproductive age who suffer from anemia can cause health, welfare and socio-economic problems for Indonesia because it is quite large in number. This is because the health of adolescents greatly determines the success of health development, especially in creating qualified future generations. In addition, anemia affects pregnant women, which in turn increases the morbidity and mortality rates for mothers and babies. 
Anemia was on the second place of the top ten diseases at public health center of Cikupa during the period from 01 June - 31 August 2018. The number of anemia cases were 1073 which spread across 10 villages. Meanwhile, the data on the previous period were only 651 cases and it was in the fourth position of the top ten diseases. This should get special attention because the number of anemia cases continue to increase in the working area of the Cikupa Public Health Center. There were 26 adolescent girls of the total cases of anemia in high school students who went to Cikupa Public Health Center [9]. Therefore, this study aims to perform early detection of anemia, improve knowledge about anemia, and improve adolescent behavior in order to reduce the cases of anemia and its complications in the future.

\section{Method}

The research employed descriptive quantitative analysis and was conducted at High School or Sekolah Menengah Atas Negeri (SMA N) 4 Cikupa. The inclusion criteria in this study were all high school female students and the exclusion criteria were students who refused or afraid of blood draw. There were 44 students as sample which was taken using simple random sampling. The data related to knowledge, attitudes and behaviour were obtained from questionnaire. Haemoglobin measurement was carried out at the Cikupa Public Health Centre laboratory which had been standardized. The intervention program included counselling with booklet, presentation, and exercise to reduce cases of anaemia. Data analysis was carried out descriptively. This research had attained permission from the Faculty of Medicine, Tarumanagara University.

\section{Results and Discussion}

\subsection{Result}

The research showed that $97,72 \%$ of 44 respondents had improved their knowledge about anemia after given intervention and $72,72 \%$ had better behavior in responding to anemia. On the other hand, there were $25 \%$ of the respondents that were diagnosed with anemia. All the respondents (100\%) were given adding blood tablets, joining exercise and were given booklets. More details can be seen in table 1 .

Table 1. Result of Descriptive Analysis After Given Intervention

\begin{tabular}{lcc}
\hline \multicolumn{1}{c}{ Variable } & $\mathbf{n}$ & $\%$ \\
\hline Knowledge & 43 & 97,72 \\
Improve & 0 & 0 \\
Remain the same & 1 & 2,28 \\
Decline & 32 & 72,72 \\
Behaviour & 11 & 25 \\
$\quad$ Getting Better & 1 & 2,28 \\
Remain the same & & \\
Decline & 11 & 25 \\
Anemia & 33 & 75 \\
Positive & & 100 \\
Negative & 44 & 0 \\
Adding blood tablets & 0 & 100 \\
Receive & & 0 \\
Do not Receive & 44 & 100 \\
Exercise & 0 & 0 \\
Join & & \\
Do not join & 44 & \\
Booklet & 0 & \\
Receive & & \\
Do not receive & & \\
\hline
\end{tabular}

\subsection{Discussion}

Previous studies have stated that the main cause of anemia in Indonesia is a lack of knowledge about anemia which results in a high rate of anemia. Therefore, it is necessary to carry out educational activities regarding anemia, the dangers of anemia and prevention so that the prevalence of anemia among adolescent girls can be suppressed [10]. One of the causes of the high prevalence rate of anemia is the unhealthy diet of adolescents. Lack 
of knowledge about anemia causes unhealthy adolescent eating patterns, resulting in bad attitudes and behavior in term of health [11].

Other studies suggest that there is a relationship among knowledge, attitudes, family education, and the incidence of anemia [12-15]. It is because good knowledge tends to have preventive behavior toward anemia [16,17]. One of the preventions of anemia done by the government is the program of giving Adding Blood Tablets or Tablet Tambah Darah (TTD) or iron tablet to reduce anemia among high school adolescent girls and pregnant women. There are some studies that show an association between iron supplement intake and the incidence of anemia among adolescent girls [15]. However, in 2018 there were $23.8 \%$ of teenage girls who did not get iron tablets and only $1.4 \%$ who consumed $\geq 52$ iron tablets obtained at school [8]. Adolescent girls who have good knowledge about anemia will consume iron tablets during menstruation and have an impact on the lower rate of anemia [18]. One way to improve adolescent knowledge about anemia is to create educational media or do educational activities.

The results of this study indicated that students got knowledge improvement and better behaviour or attitude toward anemia after they received intervention in the form of counseling with presentations, booklets, and exercise. It is in line with previous research that there was an improvement in knowledge about anemia after carrying out educational activities both with booklet and without booklet [19].

The implementation of health promotion requires the right media to convey messages so that goals are maximally achieved. The means of information also need to be considered as best as possible. One of the means of information is electronic media i.e. LCD, video and PowerPoint. This study used PowerPoint in delivering presentations. PowerPoint can make it easier for respondents to receive the material presented because it covers visual and auditory aspect, such as being able to display animations, still or moving images, attractive colors and others [20,21]. This method of counselling will improve knowledge about the material on anemia that is discussed and is expected to contribute in improving attitudes and behavior in healthy living.

In addition, this study also uses audio-visual media in the form of films or videos which are used as anemia exercise demonstrations. This is because the video is more dynamic and realistic so that the target will understand the material presented better $[20,22]$. The printed media that are often used in counseling are leaflets and booklets. Counseling which was carried out by researchers used booklets because they provide a lot of space for educational information for cadres who will evaluate the students later. Booklets are static media that prioritize visual messages and involve various colors. The function of static media is to provide a more detailed and easier explanation compared to the oral method. Moreover, static media are easy to manufacture and reproduce, durable, cheap, does not need electricity, and handy [20]. Based on the results and explanations above, it shows that improved knowledge and good attitudes are important factors in reducing the prevalence of anemia among adolescent girls.

\section{Conclusion}

The provision of interventions can improve knowledge and attitudes toward anemia, so that it can reduce the prevalence of anemia. All students of High School or Sekolah Menengah Atas Negeri (SMA N) 4 Cikupa received adding blood tablets to prevent anemia. The formation of cadres was aimed to monitor the consumption of adding blood tablets in order to prevent anemia in the future.

\section{References}

1. Kędziora-Kornatowska K, Mądra-Gackowska K, Gackowski M. Anemia. Encyclopedia of Biomedical Gerontology. 2019;1:222-228.

2. DeLoughery TG. Iron Deficiency Anemia. Medical Clinics of North America. 2017;101(2):319-332.

3. Camaschella C. Iron-deficiency anemia. New England Journal of Medicine. 2015; 372:1832-1843.

4. Gebreegziabiher G, Etana B, Niggusie D. Determinants of Anemia among Children Aged 
6-59 Months Living in Kilte Awulaelo Woreda, Northern Ethiopia. Anemia. 2014:1-9.

5. McLean E, Cogswell M, Egli I, Wojdyla D, De Benoist B. Worldwide prevalence of anemia, WHO Vitamin and Mineral Nutrition Information System, 1993-2005. Public Health Nutr. 2010.

6. World Health Organization. The global prevalence of anaemia in 2011. WHO. 2015.

7. Kementerian Kesehatan RI Badan Penelitian dan Pengembangan. Laporan Riset Kesehatan Dasar Nasional (RISKESDAS) 2013. Kementrian Kesehat Republik Indones. 2013.

8. Kementerian Kesehatan RI Badan Penelitian dan Pengembangan. Laporan Riset Kesehatan Dasar Nasional (RISKESDAS) 2018. Kementrian Kesehat Republik Indones. 2018

9. Dinkes Provinsi Banten. Profil Kesehatan Provinsi Banten Tahun 2018. Dinas Kesehatan Provinsi Banten. 2018.

10. Fajriyah N, Fitriyanto M. Gambaran Tingkat Pengetahuan tentang Anemia pada Remaja Putri. J IIm Kesehat. 2016;9(1).

11. Suryani D, Hafiani R, Junita R. Analisis Pola Makan dan Anemia Gizi Besi pada Remaja Putri Kota Bengkulu. J Kesehat Masy Andalas. 2017;10(1):11-18.

12. Martini. Faktor - Faktor yang Berhubungan dengan Kejadian Anemia pada Remaja Putri di MAN 1 Metro. J Kesehat Metro Sai Wawai. 2015;8(1):1-7.

13. Harahap NR. Faktor- Faktor yang Berhubungan dengan Kejadian Anemia pada Remaja Putri. Nurs Arts. 2018;12(2):78-90.

14. Amir N, Djokosujono K. Faktor-Faktor yang Berhubungan dengan Konsumsi Tablet Tambah Darah (TTD) pada Remaja Putri di Indonesia: Literatur Review. Kedokt Dan Kesehat 2019;15(2):119-129.

15. Listiana A. Analisis Faktor-Faktor yang Berhubungan dengan Kejadian Anemia Gizi Besi pada Remaja Putri di SMKN 1 Terbanggi Besar Lampung Tengah. J Kesehat. 2016;7(3):455-469.

16. Mularsih S. Hubungan Pengetahuan Remaja Putri Tentang Anemia dengan Perilaku Pencegahan Anemia Pada Saat Menstruasi di SMK Nusa Bhakti Kota Semarang. $J$ Kebidanan 2017;6(2):80-85.

17. Kalsum U, Halim R. Kebiasaan Sarapan Pagi Berhubungan dengan Kejadian Anemia pada Remaja di SMA Negeri 8 Muaro Jambi. J Penelit Univ Jambi Seri Sains. 2016;7(1):233-238.

18. Angrainy R, Fitri L, Wulandari V. Pengetahuan Remaja Putri Tentang Konsumsi Tablet FE pada Saat Menstruasi Pengan Anemia. J Endur. 2019;4(2):343-349.

19. Rohim AN, Zulaekah S, Kusumawati Y. Perbedaan Pengetahuan Anemia pada Remaja Putri Setelah Diberi Pendidikan dengan Metode Ceramah Tanpa Media dan Ceramah Dengan Media Buku Cerita. J Kesehat. 2017;1(2):60-71.

20. Jatmika Septi Ema Dwi, Muchsin Maulana KSM. Buku Ajar Pengembangan Media Promosi Kesehatan. Yogkarta: K-Media Yogyakarta; 2019.

21. Lubis DR, Putri AD, Binawan U. Peran Media Promosi Kesehatan terhadap Minat Wanita Usia Subur (WUS) untuk Melakukan Deteksi Dini CA Servik dengan Pemeriksaan IVA Test. Pros Semin Nas Stikes Syedza Saintika. 2021;1(1):568-576.

22. Siti Masfiah, Elviera Gamelia, Arrum Firda A.M AP. Efektifitas Pelatihan Media AudioVisual Terkait Anemia Ibu Hamil dalam Peningkatan Kompetensi; The Effectiveness of Media Training for Making Animated Films about Pregnant Suffers Anemia to Improve The Knowledge and Skills of Health Promoter in Banyumas. J Kesmas Indones. 2017;9(1):12-22. 